\title{
KONSTRUKSI PEMBANGUNAN HUKUM KELUARGA DI INDONESIA MELALUI PENDEKATAN PSIKOLOGI
}

\author{
Danu Aris Setiyanto
}

Yayasan Islam Al-I'hitisham

e-mail: danuaris07@gmail.com

\begin{abstract}
The purpose of this article is to explain the importance of psychology in the construction of family law in Indonesia and knowing reconstruction of family law development in Indonesia with a psychological approach. This is motivated lack of family law studies using psychological approaches and is an effort to contribute the development of family law from a variety of perspectives, especially with the approach of psychology. This study included literature research using multiple sources related to research problems. The results of this study indicate the development of family law in Indonesia is still less of a concern with the psychological approach. Construction of family law development in Indonesia through the psychological approach can at least be associated with three things about family education, emotional maturity, and handling partner violence.
\end{abstract}

[1

Tujuan artikel ini adalah menjelaskan urgensi psikologi dalam kontruksi hukum keluarga di Indonesia dan mengetahui rekontruksi pembangunan hukum keluarga di Indonesia dengan pendekatan psikologi. Hal ini dilatarbelakangi minimnya kajian hukum keluarga yang menggunakan pendekatan psikologi dan merupakan upaya kontribusi pengembangan hukum keluarga dari berbagai perspektif terutama dengan pendekatan psikologi. Penelitian ini termasuk penelitian pustaka yang menggunakan beberapa sumber yang terkait dengan permasalahan penelitian. Hasil penelitian ini menunjukkan pembangunan hukum keluarga di Indonesia memang masih kurang dari perhatian dengan pendekatan psikologis. Kontruksi pembangunan hukum keluarga di Indonesia melalui pendekatan psikologi setidaknya dapat terkait dengan tiga hal, yaitu tentang pendidikan keluarga, kematangan emosi, dan penangangan kekerasan pasangan.

Keywords: konstruksi; hukum keluarga; psikologi 


\section{Pendahuluan}

Adanya Undang-Undang (UU) Perkawinan di Indonesia bisa saja disebut sebagai tonggak revolusi awal pembangunan segala hukum keluarga. Pengaturan melalui regulasi menunjukkan adanya penekanan pentingnya sebuah keluarga dalam sebuah bangsa dan negara. Keluarga telah dianggap negara sebagai unit terkecil dari negara yang berperan aktif terhadap kemajuan bangsa yang selalu harus diperhatikan. Namun pemahaman terhadap pembangunan hukum keluarga Islam selama ini memang terkesan didominasi hanya terfokus terhadap hal-hal yang normatif semata. Pendekatan yuridis yang digunakan hanya terbebani dengan kebolehan atau tidaknya dari setiap peristiwa hukum keluarga. ${ }^{1}$ Pemahaman ini pun juga tidak terlepas dari pemikiran fikih dalam kitab-kitab klasik yang menjadi dasar pembangunan hukum keluarga selama ini.

Pembangunan keluarga pada prinsipnya bertujuan terwujudnya keluarga sakinah atau keluarga yang bahagia. Namun pembangunan yang hanya menekankan hukum normatif semata memang bisa dianggap tidak cukup untuk mengatasi kompleksitas permasalahan keluarga di abad modern. Dalam hal ini diperlukan pendekatan atau aspek lain yang dapat dipadukan dengan hukum keluarga Islam sehingga menimbulkan kesatuan yang untuk yang lebih komprehensif mencapai tujuan perkawinan.

Tulisan Khoiruddin Nasution "Arah Pembangunan Hukum Keluarga Islam di Indonesia Pendekatan Intgratif dan Interkonektif dalam Membangun Keluarga Sakinah", merupakan salah satu rujukan penting dalam menemukan konsep arah membangun keluarga untuk masa mendatang. ${ }^{2}$ Dia menekankan pentingnya pengetahuan kehidupan keluarga sejak dini dan menawarkan sejumlah subjek ilmu yang perlu ditelaah lebih lanjut dalam membangun keluarga yang sejahtera. Menurutnya, masih diperlukan adanya berbagai pendekatan dan aspek yang melingkupi hukum keluarga yang selama ini masih belum banyak dikaji.

\footnotetext{
${ }_{1}^{1}$ Khoiruddin Nasution, "Arah Pembangunan Hukum Keluarga: Pendekatan Integratif dan Interkonektif dalam Pembangunan Keluarga Sakinah", dalam As-Syir'ah: Jurnall Ilmu Syari'ah dan Hukum, Vol. 46 No. I, Januari-Juni 2012, h. 84.
}

2Ibid., h. 84. 
Tulisan ini merupakan salah satu wujud dari kajian pembangunan hukum keluarga dari perspektif psikologi keluarga dan dikaitkan dengan hukum keluarga di Indonesia. Pendekatan yang digunakan dalam tulisan ini adalah pendekatan psikologi. Pendekatan yang menekankan adanya tingkah laku manusia sebagai gejala dari jiwanya. Dalam pembahasan ini juga diberikan penjelasan secara umum tentang psikologi Islam, yaitu psikologi yang dibangun dalam hal ini adalah psikologi Islam yang mendasarkan segala hal dengan sumber-sumber hukum ajaran Islam.

Berdasarkan penjelasan di atas, maka tujuan penulisan ini secara teoritis dapat dijadikan khasanah keilmuan dalam rekonstruksi pembangunan hukum Keluarga Islam dengan pendekatan psikologi. Secara toeritis, bagi para praktisi hukum keluarga dapat menjadi penggerak hati dan jiwa dalam menciptakan dan menegakkan regulasi keluarga yang lebih humanis dan lebih dapat menyelesaikan segala permasalahan kompleksitas hukum keluarga secara lebih bijak dan tepat.

\section{Konsep Psikologi dan Keluarga}

\section{Mengenal Psikologi Islam}

Psikologi berasal dari kata dalam bahasa Yunani psychology yang merupakan gabungan dan kata psyche dan logos. Psyche berarti jiwa dan logos berarti ilmu. Secara harfiah psikologi diartikan sebagal ilmu jiwa. Psikologi merupakan salah satu ilmu yang berumur sekitar 100 tahun. Sedangkan psikologi keluarga sendiri merupakan kajian yang cukup baru yang dikenal sekitar 25 tahun. $^{3}$

Psikologi merupakan salah satu cabang ilmu pengetahuan yang berfokus kepada tingkah laku manusia yang diasumsikan sebagai bentuk gejala dari jiwanya. Bahasa lain dari psikologi adalah ilmu jiwa. Namun sebenarnya objek psikologi adalah tingkah laku manusia dengan melalui perenungan, pengamatan dan laboratorium, kemudian menghubungkan dengan tingkah laku lain yang selanjutnya dirumuskan dalam hukum-hukum kejiwaaan manusia. ${ }^{4}$

\footnotetext{
${ }^{3}$ William M. Pinsof, Jay L. Lebow (eds.), Family Psychology: The Art of The Science (New York: Oxford University Press, 2005), h. 3.

${ }^{4}$ Achmad Mubarok, Psikologi Keluarga (Malang: Madani, 2016), h. 2.
} 
Psikologi Islam sendiri merupakan ilmu pengetahuan yang masih relatif baru. Berbagai perjuangan dilakukan oleh kaum cendekiawan Muslim untuk memperkenalkan psikologi keluarga. Perjuangan dilakukan dimulai dari tingkat diskusi, seminar, penelitian ilmiah terus dilakukan. Selain itu, segala hasil penelitian kemudian dipublikasikan dalam buku dan jurnal sehingga menambah wawasan keilmuan.

Istilah Psikologi Islam memang tidak mudah begitu saja terlepas dari istilah psikolog Barat. Kemunculan Psikologi Islam tidak terlepas dari mahasiswa Muslim yang mendalami psikologi Barat yang kemudian mereka membanding-bandingkan antara psikolog Barat dan apa yang ada dalam Islam. Selanjutnya mereka kemudian mengkritisi pandangan-pandangan psikolog Barat dan akhirnya mengalihkan perhatian kepada al-Qur'an, hadis, dan khasanah-khasanah klasik Islam yang membahas tentang nafs dan manusia. ${ }^{5}$

Kelahiran psikologi Islam bisa saja disebut sebagai ekspresi ketidakpuasan terhadap aliran mazhab psikologi yang ada. Perkembangan psikologi dikuasai oleh empat mazhab besar yaitu psikoanalisa, behaviourisme, humanis, dan transpersonal. Jika psikologi Islam berkembang maka bisa saja disebut sebagai mazhab besar yang kelima. Kehadiran psikologi Islam juga merupakan wujud dukungan dalam mengadopsi konsep-konsep psikologi Islam dengan mengangkat pesan Ilahi baik dari al-Qur'an, hadis, dan penafsiran para ulama terkait hal tersebut. Hal ini berimplikasi dengan mengabaikan pandangan-pandangan psikologi yang berasal dari mayoritas non-Islam yang sudah lama berkembang. ${ }^{6}$

Achmad Mubarok dalam bukunya Psikologi Keluarga menjelaskan bahwa sepanjang sejarah ada pertanyan tentang manusia yang tak selesai untuk dijawab. Pertanyaan itu adalah dari mana, mau kemana, dan untuk apa hidup di bumi. Islam telah menegaskan bahwa manusia berasal dan akan kembali kepada Tuhannya. Namun perdebatan tentang untuk apa hidup di bumi belum bisa terjadi kekompakan untuk menjawabnya. Walaupun demikian, pertanyaan ketiga inilah yang dianggap telah melahirkan ilmu seperti filsafat, psikologi,

\footnotetext{
${ }^{5}$ Achmad Mubarok, Psikologi Keluarga..., h. 5.

'Zaharuddin, "Telaah Kritis terhadap Pemikiran Psikologi Islam Muhammad Utsman Najati," dalam Psikis: Jurnal Psikologi Islami, Vol. 1, No. 2, 2015, h. 95-96.
} 
etika, ekonomi, politik dan lain sebagainya. ${ }^{7}$ Maka pembahasan dalam subbab ini penting ditekankan adanya penjelasan mengapa keluarga dibentuk dan ada dalam kehidupan manusia dengan pendekatan psikologi.

\section{Konsep Keluarga}

Keluarga berasal dari bahasa Sansekerta yaitu kula dan warga yang kemudian digabungkan menjadi kulawarga. Keluarga adalah sekelompok orang dengan ikatan perkawinan, darah, atau adopsi; terdiri dari satu orang kepala rumah tangga, interaksi dan komunikasi satu sama lainnya dalam peran suami istri yang saling menghormati, ibu dan ayah, anak laki-laki dan perempuan, saudara laki-laki dan perempuan, dan menciptakan serta mempertahankan kebudayaannya. Keluarga merupakan suatu kelompok sosial yang bersifat langgeng berdasarkan hubungan pernikahan dan hubungan darah. Keluarga adalah tempat pertama bagi anak, lingkungan pertama yang memberi penampungan baginya, tempat anak akan memperoleh rasa aman. Dengan demikian dapat kita simpulkan dari beberapa tokoh di atas adalah bahwa psikologi keluarga adalah ilmu yang mempelajari tentang gejala jiwa dalam sebuah rumah tangga atau keluarga.

Kata "keluarga" dalam Kamus Besar Bahasa Indonesia diartikan ibu dan bapak beserta anak-anaknya; seisi rumah. ${ }^{8}$ Widaningsih menjelaskan pengertian keluarga sebagaimana dikutip oleh Anita Rahmawaty, keluarga merupakan sub sistem dari masyarakat yang memiliki struktur sosial dan sistemnya sendiri. Keluarga memiliki fungsi strategis dalam menanamkan nilai-nilai kesetaraan dalam setiap aktivitas dan pola relasi antar anggota keluarga. Menurutnya, dalam keluargalah semua struktur, peran, dan fungsi sebuah sistem berada. ${ }^{9}$

Hasan Basri menjelaskan bahwa keluarga adalah unit terkecil dari sistem kehidupan sosial yang terdiri dari sekurang-kurangnya, suami dan istri. Menurutnya, keluarga muncul karena diawali oleh pertemuan dua anak manusia,

\footnotetext{
${ }^{7}$ Achmad Mubarok, Psikologi Keluarga..., h. 2.

${ }^{8}$ Tim Pusat Bahasa, Kamus Besar Bahasa Indonesia (Jakarta: Pusat Bahasa, 2008), h. 721.

${ }^{9}$ Anita Rahmawaty, "Harmoni dalam Keluarga Perempuan Karir: Upaya Mewujudkan Kesetaraan dan Keadilan Gender dalam Keluarga", dalam Jurnal Palastren, Vol. 8, No. 1, Juni 2015, h. 2.
} 
yaitu laki-laki dan perempuan dalam satu ikatan pernikahan yang sesuai dengan syariat. Oleh sebab itu kehidupan bersama laki-laki dan perempuan yang tanpa didahului perkawinan tidak bisa disebut sebagai keluarga.10

Dalam hukum keluarga di Indonesia, keluarga terbentuk karena adanya perkawinan yang sah baik secara hukum negara dan agama. Perkawinan harus dicatatakan untuk mencapai legal formal perkawinan secara negara, dan perkawinan tersebut harus dilaksanakan sesuai agama dan kepercayaan masing-masing pasangan calon. ${ }^{11}$ Urgensi pencatatan dan pengesahan oleh negara berperan dalam upaya negara melindungi warga negara dalam membangun keluarga yang dapat menjamin hak dan kewajiban setiap anggota keluarga. Adapun pengesahan berdasarkan agama merupakan bentuk nyata bahwa negara menegaskan dan mengingatkan kepada masyarakat Indonesia tentang makna perkawinan harus mencakup hubungan dengan Tuhan dan bukan semata-mata hubungan perdata.

Adapun tujuan dari perkawinan adalah untuk mencapai sebuah keluarga yang bahagia kekal berdasarkan Ketuhanan Yang Maha Esa. Dalam mencapai tujuan ini perkawinan memang tidak lepas dari segala aspek kehidupan, baik dari sisi material maupun emosional. Peran sisi material perkawinan telah jelas disebutkan dalam UU Perkawinan terutama dalam persoalan hak dan kewajiban suami isteri. Adapun pada sisi emosional, psikologi berperan penting dalam memberikan solusi setiap permasalahan, baik antisipasi maupun memberikan solusi setiap kasus permasalahan keluarga.

Mencapai tujuan perkawinan dalam keluarga memang tidak cukup dengan pendekatan yuridis semata. Pendekatan psikologi Islam sangatlah penting untuk menjelaskan hakikat manusia sebagai makhluk individu dan makhluk sosial karena pada prinsipnya psikologi menjadikan manusia sebagai subjek dan objek sekaligus. Melalui pendekatan ini diharapkan penegakkan dan penangangan segala kasus hukum keluarga dapat diselesaikan dengan baik dan lebih mengutamakan keadilan.

\footnotetext{
${ }^{10}$ Hasan Basri, "Nutrisi Cinta: Strategi Menggapai Keluarga Sakinah", dalam Humaira: Majalah Keluarga Sakinah, Vol. I/No.1/Mei 2013/Rajab 1434 H, h. 9.

${ }^{11}$ Lihat dalam UU Perkawinan Pasal 2 ayat (1) dan ayat (2).
} 


\section{Urgensi Psikologi dalam Permasalahan Keluarga}

Relasi psikologi dan keluarga memang masih terasa asing untuk didapatkan dalam berbagai literatur. Padahal psikologi pendidikan sudah ada sangat lama yang berperan penting dalam memberikan konseling pendidikan kepada siswa-siswa bermasalah. Psikologi pendidikan terwujud dengan adanya guru BP atau guru Bimbingan di setiap sekolah. Padahal permasalahan keluarga lebih kompleks dibandingkan dengan yang ada di sekolah.

Permasalahan keluarga memang masih jarang ditangani secara profesional oleh satu lembaga tertentu dari psikolog keluarga Islam. Hal ini disebabkan karena adanya faktor fenomena universal sosial yang ada dalam masyarakat sehingga permasalahan keluarga ditangani secara alamiah semata. Padahal keluarga merupakan unsur penting dalam kehidupan manusia yang akan datang. ${ }^{12}$

Di Indonesia sendiri permasalahan keluarga memang masih relatif jarang dikonsultasikan kepada psikolog keluarga. Segala permasalahan biasanya diselesaikan secara berjenjang dimulai dari keluarga kecil, keluarga besar, hingga akhirnya diselesaikan lewat pengadilan. Lembaga lain yang juga terkait penting adalah Kantor Urusan Agama (KUA), walaupun dalam lembaga ini terdapat lembaga konsultasi permasalahan keluarga atau disebut BP4 (Badan Penasehat Pembinaan dan Pelestarian Perkawinan) namun peran dan fungsinya belum bisa berjalan dengan maksimal seiring dengan meningkatnya angka perceraian setiap tahun. Dengan kondisi yang demikian KUA hendaknya bukan saja dimaknai sebagai lembaga pencatat nikah semata, namun juga sebagai konselor pernikahan, sehingga dapat memberikan nasehat perkawinan dan mampu menyelesaikan segala pertikaian keluarga secara profesional.

Terlepas dari fakta tersebut di atas, pada hakikatnya aspek psikologi sangat penting dalam memecahkan permasalahan keluarga. Hal ini karena psikologi dapat membantu menjelaskan kondisi kejiwaan pasangan suami istri untuk mendapatkan tujuan perkawinan sakinah, mawadah, warahmah. Psikologi keluarga juga membantu memberikan solusi terkait dengan permasalahan keluarga yang berkaitan dengan permasalahan kejiwaan dan

\footnotetext{
${ }^{12}$ Achmad Mubarok, Psikologi Keluarga..., h. 2.
} 
atau permasalahan lain yang berakibat kepada faktor kejiwaan pasangan. Psikologi keluarga sebaiknya disusun dalam sebuah buku bimbingan calon pengantin sehingga dapat memberikan bekal untuk menjalani rumah tangga dengan baik. Selain itu, psikologi hukum keluarga juga sangat dibutuhkan untuk mengatasi persoalan-persoalan yang berkaitan jiwa, proses terjadinya saling cinta, memilih pasangan, perbedaan karakter, kasih sayang, cemburu, benci, marah dan emosi lain.

Adapun urgensi psikologi tersebut dapat diwujudkan dengan beberapa hal. Dalam pembahasan ini akan dijelaskan urgensi psikologi dalam menyelesaikan permasalahan keluarga dengan membahas tiga isu penting, yaitu pendidikan keluarga, emosi, dan partner violence (kekerasan pasangan). Ketiga permasalahan ini sangat penting untuk dikaji dalam lingkup hukum keluarga di Indonesia karena berbagai permasalahan keluarga di Indonesia sebagian besar tidak lepas dari isu tersebut.

\section{Pendidikan Keluarga}

Salah satu metode menciptakan keluarga sakinah, mawaddah dan rahmah adalah melalui pendidikan pra nikah dan pendampingan menuju keluarga sakinah. Selain itu adalah melakukan evaluasi terhadap progam kursus pra nikah dan pembinaan/pendamingan untuk menuju keluarga yang sakīnah, mawaddah wa rahmah. Adapun secara umum dapat dibagi menjadi dua bagian, yaitu: 1) sebelum nikah dan; 2) sesudah nikah. Adapun yang bisa dilakukan sebelum pernikahan, antara lain: 1) melakukan pendidikan pra nikah;2) memberikan pengetahuan agama; 3) mendeskripsikan tokoh-tokoh yang bisa dijadikan teladan masyarakat untuk menciptakan tujuan perkawinan; 4) membuka biro jodoh yang tepat dengan memperhatikan aturan hukum dan norma dalam masyarakat; 5) memberikan konsultasi permasalahan sebelum pernikahan.

Adapun yang bisa dilakukan setelah pernikahan antara lain, yaitu: 1) membuka layanan konseling permasalahan perkawinan; 2) melakukan pengawasan dan memberikan pembinaan terhadap permasalahan keluarga di masyarakat; 3) memberikan pendampingan keluarga untuk mencapai tujuan perkawinan; 4) bekerja sama dengan berbagai instansi yang terkait dengan keluarga untuk melakukan pembinaan kesejahteraan, kerukunan, kebahagiaan keluarga; 5) melakukan kegiatan keagamaan dengan tema-tema hukum kelurga terutama 
yang terkait dengan keluarga sakinah, mawaddah wa rahmah; 6) melakukan studi banding terhadap beberapa instansi yang menangani hukum keluarga; 7) membuat konsep dan materi modul yang berkaitan dengan bimbingan keluarga sakinah.

\section{Emosi dalam Keluarga}

Kata emosi berasal dari kata latin untuk bergerak. Dalam psikologi, emosi adalah sistem pengolahan informasi tingkat tinggi bukan sekadar sensasi. Secara teori, emosi terdiri dari dua unsur, yaitu; pertama, penilaian cepat terhadap isyarat lingkungan yang berkaitan dengan kunci kebutuhan hidup dan imperatif; kedua, sensasi tubuh.

Ada tiga alasan yang menonjol mengapa penyebab emosi sering dikesampingkan dalam memecahkan masalah pasangan suami isteri. Pertama, konteks budaya dan profesionalisme dimana beberapa hal dalam terapi keluarga yang dikembangkan telah sangat ambivalen (perasaan yang bertentangan) tentang emosi. Adanya model patriarki kesehatan dan kesejahteraan menekankan rasionalitas dan kontrol diri atas emosi dan ekspresi emosional, yang telah dikaitkan dengan feminin. Kedua, emosi mungkin telah terpinggirkan karena sifat emosi tidak diungkapkan dengan jelas. Hal ini tidak hanya masalah dalam dirinya sendiri tapi kemudian mengakibatkan emosi yang dipertimbangkan dengan cara agak dangkal dan terpolarisasi menjadi agen perubahan terapeutik. Ketiga, emosi mungkin telah terpinggirkan karena hanya baru-baru ini bahwa penelitian telah secara substansial memiliki keunggulan emosi di arena hubungan intim dan definisi kemitraan dewasa, dan hanya baru-baru ini bahwa model pasangan dan keluarga terapi yang mengemban keutamaan emosi dan penggunaannya menjadi agen perubahan telah terbukti efektif. ${ }^{13}$

Menurut teori attachment, tidak ada hal seperti kemerdekaan penuh dari orang lain. Namun teori attachment merupakan teori yang bertujuan untuk membangkitkan dan menggunakan emosi untuk menciptakan pengalaman baru tentang hubungan emosional dan interaksi baru yang efektif. Hasil penelitian juga menunjukkan bahwa terapi beberapa model yang berfokus pada emosi mungkin lebih mahir mendorong adanya perubahan yang abadi dan

13William M. Pinsof, Jay L. Lebow (eds.), Family Psychology..., h. 92-93. 
meminimalkan kambuh daripada pendekatan lain yang tidak menangani mempengaruhi dengan cara yang sama. ${ }^{14}$

Pada prinsipnya keluarga tidak terlepas dari adanya kematangan emosi antar pribadi dalam semua anggota keluarga. Untuk bisa menyatukan antara satu anggota keluarga dengan yang lain, maka diperlukan pengorbanan, pengertian, kematangan emosi dan hal yang harus disadari oleh pihak suami istri. Sehingga penyesuaian diri pasangan suami istri secara psikologis sangatlah diperlukan. Hal ini untuk menciptakan emosi yang stabil, menyadari tanggungjawab, terintegrasi segenap komponen kejiwaan. Mempunyai tujuan dan arah hidup yang jelas, dan produktif-kreatif serta etis-religius. ${ }^{15}$

\section{Partner Violence}

Partner Violence adalah kekerasan pasangan. Kekerasan yang dimaksud bisa saja kekerasan fisik dan atau kekerasan non fisik. Kekerasan juga terkait perkataan kasar, pemaksaan kehendak, dan kekerasan psikis dan lain-lain. Dalam hal ini yang sering melakukan adalah laki-laki, walaupun tidak dipungkiri wanita juga melakukan kekerasan terhadap pasangan. ${ }^{16}$

Pada umumnya kekerasan dilakukan oleh laki-laki karena adanya perasaan superior dibandingkan dengan perempuan. Laki-laki pada umumnya secara fisik juga lebih tegas, lebih kuat dan memilki kekuasan dalam bidang ekonomi. Tingkat emosi negatif laki-laki yang lebih tinggi didukung dengan fisik yang lebih kuat akan memunculkan jiwa superior. Hal tersebut juga dipengaruhi budaya masyarakat yang menjadikan laki-laki sebagai penguasa rumah tangga. ${ }^{17}$

Dari sisi lain terdapat teori belajar sosial (social learning theory) berkaitan dengan lingkungan sosial. Yang dimaksud di sini adalah bahwa jika di lingkungan anak terjadi kekerasan, maka anak akan melakukan perilaku seperti itu. ${ }^{18}$ Lingkungan sosial yang dimaksud bukan hanya tertuju kepada perilaku

\footnotetext{
${ }^{14}$ Ibid., h. 97-99.

15Nova Anissa, dan Agustin Handayani, "Hubungan antara Konsep Diri dan Kematangan Emosi dengan Penyesuaian Diri Istri yang Tinggal Bersama Keluarga Suami", dalam Jurnal Psikologi Pitutur, Vol. 1, No. 1, Juni 2012, h. 59-60.

16William M. Pinsof, Jay L. Lebow (eds.), Family Psychology..., h. 223.

${ }^{17} \mathrm{Ibid}$.

18 Ibid.
} 
orang tua, tetapi juga kepada tayangan di TV dan teman-teman sebaya. Jadi teori ini menyatakan bahwa anak cenderung akan berperilaku sesuai dengan kondisi lingkungan sosial. Anak yang mengalami kekerasan atau melihat kekerasan maka akan bisa menjadi trauma dan atau mungkin melakukan hal yang sama untuk melakukan kekerasan.

\section{Kontruksi Pembangunan Hukum Keluarga di Indonesia melalui Pendekatan Psikologi}

Dalam hal ini, hukum keluarga dapat dikatakan sebagai kebijakan publik dalam progam-progam sosial yang bertujuan untuk meningkatkan kualitas hidup dan dapat mengantisipasi kegagalan progam adminitrasi. Selain itu kebijakan yang dibentuk hendaknya memiliki dampak yang bagus dalam kehidupan keluarga di masa mendatang. ${ }^{19}$ Dengan demikian, sangat penting adanya sebuah kontruksi hukum keluarga di Indonesia dengan berbagai pendekatan, salah satunya adalah pendekatan psikologi.

Pembangunan hukum keluarga dengan pendekatan psikologi merupakan bentuk pengembangan kebutuhan kompetensi hukum keluarga yang lebih komprehensif. Selain itu, dapat menambah khazanah keilmuan untuk memperluas jangkauan hukum keluarga yang selama ini lebih dekat dengan aspek normatif semata. Selanjutnya, pendekatan psikologi dalam hukum keluarga diharapkan dapat membantu menangani berbagai kasus keluarga yang tidak bisa diselesaikan dengan pendekatan yang lain.

Terlepas dari hal di atas, pendekatan psikologi masih relatif baru dalam memasuki ranah hukum, yaitu sejak awal abad ke-20. Namun pada prinsipnya kajian dalam psikologi dan hukum memiliki tujuan dalam membantu hukum mencapai kebenaran atau keadilan. Beberapa kajian yang muncul dalam psikologi hukum adalah psikologi penegakkan hukum, psikologi untuk menangani narapidana baru, psikologi forensik, dan psikologi hukum. ${ }^{20}$

Apabila pendekatan psikologi dikaitkan dengan tiga isu hukum keluarga di atas (pendidikan keluarga, emosi, dan kekerasan pasangan) maka peran psiko-

\footnotetext{
19David H. Olson dan Brent C. Miller (ed.), Family Studies: Review Yearbook; A General Framework for Family Impact Analysis (London/ Beverly Hills/ New Delhi: Sage Publiction:, 1983), h. 31-32.

20Ester Lianawati, Tiada Keadilan Tanpa KDRT Perspektif Psikologi Feminis (Yogyakarta: Paradigma Indonesia, 2009), h. 19.
} 
logi adalah dapat memberikan arahan dan rekonstruksi hukum keluarga baik yang formil maupun materiil. Bukan hanya itu saja psikologi juga diharapkan berperan dalam persoalan yang terjadi di luar proses peradilan. Dengan demikian, permasalahan hukum keluarga yang bersifat psikis juga bisa dapat diselesaikan dengan baik.

Di Indonesia pendidikan tentang keluarga belum bisa dikatakan berjalan maksimal. Jika ditelaah, negara sebenarnya sudah memberikan aturan tentang kursus pra nikah. Salah satunya adalah Peraturan Dirjen Bimbingan Masyarakat Islam Nomor: DJ.II/542 Tahun 2013 tentang Pedoman Penyelenggaraan Kursus Pra Nikah. Dalam peraturan tersebut sangat jelas disebutkan bahwa pengajar atau narasumber dalam kursus pra nikah, salah satunya adalah dari seorang psikolog. ${ }^{21}$ Sedangkan dalam kurikulum dan silabus yang dianjurkan dari Peraturan tersebut terdapat materi psikologi keluarga. Materi psikologi keluarga yang diberikan adalah tentang psikologi perkawinan, pengertian keluarga, ruang lingkup psikologi keluarga, upaya mencapai keluarga sakinah, dan membina hubungan dalam keluarga. ${ }^{22}$

Seorang penghulu menceritakan bahwa pembekalan tentang keluarga bagi calon pengantin adalah hal yang sangat penting. Hal ini sangat membantu kesiapan mental dan pemahaman managemen keluarga. Ketidaksiapan mental dan kurangnya memahami kompetensi tentang membangun rumah tangga, menyebabkan konflik dan kegagalan rumah tangga. Walaupun begitu penting, perhatian publik sangat masih kurang dalam hal kursus pra nikah ini. BP4 sebagai lembaga yang diberikan kewenangan dalam hal ini masih terkesan tidak maksimal menjalankan kursus calon pengantin (suscatin). Pembekalan pada umumnya hanya dilakukan seperti pengajian umum, dengan materi dan pemateri yang seadanya, dan metode yang seadanya. Selain itu hanya dilakukan dengan dengan waktu yang sangat singkat.23

\footnotetext{
${ }^{21}$ Lihat penjelasan Bab V , point 3, Peraturan Dirjen Bimbingan Masyarakat Islam Nomor: DJ.II/542 Tahun 2013 tentang Pedoman Penyelenggaraan Kursus Pra Nikah.

22Lihat lampiran Peraturan Dirjen Bimbingan Masyarakat Islam Nomor: DJ.II/542 Tahun 2013 tentang Pedoman Penyelenggaraan Kursus Pra Nikah.

23Muchson Thohier, "Pembekalan Pranikah: Siapa Peduli?" dalam http://m.kompasiana.com /muchson_thohier/pembekalan-pranikah-siapa-peduli_552bdbbb6ea8344f418b4569 diakses tanggal 22 Januari 2017.
}

36 || Volume 27, Nomor 1, April 2017

AL-AHKAM p-ISSN: 0854-4603; e-ISSN: 2502-3209 
Sehingga dapat dikatakan penanganan dalam pendidikan calon pengantin masih sangat kurang dalam tahap implementasi. Hal ini menunjukkan psikologi keluarga dalam lingkup hukum keluarga sangat masih kurang diperhatikan oleh berbagai kalangan. Padahal keluarga sendiri terbentuk karena adanya ikatan emosional untuk bisa saling memberikan kasih sayang.

Selanjutnya, kontruksi hukum keluarga di Indonesia sebaiknya bisa bersifat adaptif dalam perubahan keluarga dengan berbagai aspek dan segala konsekuensinya. Salah satu perubahan keluarga adalah berkaitan dengan peran keluarga itu sendiri terutama peran sosial dan emosional, sekalipun peran keluarga kemudian bergeser menjadi peran ekonomis.

Perubahan tersebut di atas dapat dijumpai dengan mudah di abad modern. Suami dan istri mereka meninggalkan rumah untuk bekerja di saat pagi hari, dan pulang di saat malam hari. Kondisi yang demikian menyebabkan emosi dan interaksi antara anggota keluarga menjadi berkurang. Dengan kondisi yang demikian, maka kepribadian anak bisa lebih besar dipengaruhi oleh sekolah dan lingkungan sosialnya. ${ }^{24}$

Dalam penanganan hukum keluarga, emosi memang bukanlah hal yang mudah bisa dikelola dan bahkan diabaikan dalam beberapa kasus hukum keluarga. Kondisi yang demikian mendorong konstruksi hukum yang mampu mengaktualisasikan peran normatif keluarga yang berorientasi kepada kebudayaan, moral keagamaan, kemandirian, orientasi prestasi dan kemandirian. 25

Prinsip yang penting dalam pengelolaan emosi dalam keluarga juga berkaitan erat dengan akhlak yang mulia yang dijadikan dalam bersosialisasi dan berinteraksi dalam kehidupan keluarga. Untuk dapat melakukan hal tersebut, maka hukum keluarga di Indonesia harus mampu mendorong bahwa setiap anggota keluarga memiliki tanggungjawab bersama dalam membangun keluarga yang bahagia.

Yusdani menjelaskan dalam sebuah keluarga hendaknya membangun pola interaksi keluarga yang baik, yaitu: memiliki kedewasaan dan kearifan, sehat

\footnotetext{
24Faturochman, "Revitalisasi Peran Keluarga", dalam Buletin Psikologi, Tahun IX, No. 2, Desember 2001, h. 40-41.

25Ibid, h. 42.
} 
akal, saling menghormati hak, kerjasama, setia, menjaga kehormatan keluarga, menjadi teladan, memenuhi kebutuhan seksual, dan bertingkah laku yang ma'ruf. ${ }^{26}$ Hukum perkawinan di Indonesia pada prinsipnya sudah sebagian besar sudah dapat memberikan ketetapan tersebut dalam UU Perkawinan. ${ }^{27}$ Namun, pasal yang ada dalam hal tersebut perlu dikontruksikan kembali sehingga menjadi lebih detail dan konkrit sehingga lebih mudah dalam aplikasinya di masyarakat.

Dalam membangun ke arah yang demikian, maka diperlukan suatu tindakan yang berkelanjutan yang dilakukan oleh beberapa pihak yang terkait dengan sosialisasi peran emosi dalam keluarga. Peran emosi keluarga melalui jalur hukum tentu saja dilakukan oleh pegawai pencatat nikah, konsultan keluarga, tokoh masyarakat, tokoh agama, penegak hukum, dan atau pihak lain yang terkait. Oleh sebab itu, negara hendaknya memiliki kekuatan untuk mengatur proses sosialisasi peran emosi dalam keluarga sehingga tercipta keluarga sakinah, mawaddah wa raḥmah.

Sebagai salah satu contoh kasus emosi melalui pendekatan psikologi dalam hukum keluarga adalah solusi kasus emosi perceraian. Secara hukum agama atau negara, perceraian hanya dipandang sesuatu yang boleh dilakukan tetapi dibenci untuk dilakukan. Pada kenyataanya, tidak bisa dipungkiri bahwa perceraian tidak dipengaruhi apakah sebelumnya pasangan menjalin percintaan cukup lama atau tidak, terjadi kepada keluarga harmonis atau tidak, romantis atau tidak, menikah secara megah atau tidak. Namun dalam kehidupan manusia perceraian terus terjadi, sehingga banyak orang merasa trauma, sakit hati, kecewa, depresi, dan mengalami gangguan jiwa akibat perceraian tersebut.28 Penanganan kasus hukum keluarga di Indonesia, hingga saat ini belum dapat diselesaikan melalui pendekatan psikologis hukum keluarga. Dengan demikian diharapkan dengan menjadikan pendekatan psikologi dalam penyelesaian kasus keluarga, perceraian dapat dihindarkan atau ganggguan jiwa setelah perceraian tidak terjadi pada pasangan yang melakukan perceraian.

\footnotetext{
26Yusdani, Menuju Fiqh Keluarga Progresif, Cet. II (Yogyakarta: Kaukaba, 2015), h. 208-219.

27Bisa dilihat dalam UU No. 1 Tahun 1974 tentang Perkawinan dalam beberapa pasal yang terkait dengan Kewajiban dan Hak dalam Keluarga.

${ }^{28}$ Agoes Dariyo, Memahami Psikologi Perceraian dalam Kehidupan Keluarga, dalam Jurnal Psikologi, Vol. 2 No. 2 Desember 2004, h. 94.
} 
Rekontruksi hukum keluarga dengan pendekatan psikologi yang berikutnya adalah tentang kekerasan dalam keluarga. Kekerasan dalam rumah tangga (KDRT) dapat terjadi dalam beberapa bentuk, baik fisik, psikis, seksual, dan penelantaraan rumah tangga. ${ }^{29}$ Berbagai pandangan telah berupaya untuk membangun hukum keluarga bebas dari KDRT seperti gender dan HAM. Namun masih sedikit, perhatian psikologi terhadap hukum keluarga yang dapat memberikan kontribusi dalam kasus KDRT ini.

Ester Lianawati telah yang menawarkan dan menjelaskan solusi atas problem kekerasan pasangan dengan pendekatan psikologi. Beberapa hal yang ditawarkan Ester adalah dengan menyediakan sanksi sosial sebagai alternatif hukuman atas pelaku, menjalin kerja sama dengan lembaga psikologi agar dapat menyediakan tenaga psikolog, menyediakan pendamping hukum berspektif perempuan yang handal, dan melakukan advokasi kebijakan yang diperlukan untuk mendukung korban KDRT dalam mencapai keadilan..$^{30}$ Gagasan ini memang sangat baik dan dapat dikontruksikan dalam hukum keluarga di Indonesia.

Solusi permasalahan kekerasan pasangan di atas dapat menjadi salah satu rekonstruksi hukum keluarga yang selama ini masih kaku yang hanya dengan pendekatan yuridis semata. Padahal kekerasan pasangan sendiri merupakan tindakan yang lebih kompleks yang bisa berakibat perceraian. Maka kontruksi hukum yang dibangun bukan semata-mata kepada penanganan kasus dalam sidang pengadilan. Namun juga dibutuhkan landasan yuridis berbasis psikologi tentang apa yang terjadi di luar pengadilan selama proses hukum berlangsung.

\section{Kesimpulan}

Keluarga yang terbentuk dari hasil perkawinan tidak bisa terlepas dari pendekatan psikologis. Perkawinan terbentuk karena adanya komitmen untuk saling memberikan kasih sayang. Adanya beberapa perubahan fungi keluarga dalam kehidupan modern menyebabkan kajian pendekatan yuridis belum mampu menyelesaikan kompleksitas masalah keluarga. Permasalahan kursus

\footnotetext{
29UU Nomor 23 Tahun 2004 tentang Penghapusan Kekerasan dalam Rumah Tangga.

30Ester Lianawati, Tiada Keadilan Tanpa KDRT..., h. 193-201.
} 
pra nikah bagi calon pengantian, kematangan emosi, dan adanya kekerasan pasangan dalam keluarga tidak dapat diselesaikan dengan baik dengan pendekatan yuridis semata.

Dalam hukum keluarga di Indonesia, pendidikan atau kursus pra nikah belum dapat diimplementasikan dengan baik. Padahal pedoman untuk melaksanakan telah ada. Tetapi dalam praktiknya, terdapat beberapa kekurangan seperti; kursus pra nikah dilakukan dalam waktu yang singkat, pemateri yang bukan ahlinya, dan sejumlah kendala teknis yang masih perlu dikontruksi dalam hukum keluarga di Indonesia. Pendidikan keluarga atau konseling keluarga merupakan hal penting dalam meningkatkan antisipasi permasalahan keluarga yang muncul dan penyelesaian permasalahan keluarga dengan pendekatan psikologis.

Kematangan emosi dalam hukum keluarga juga masih sangat kurang menjadi perhatian dalam hukum keluarga. Padahal dalam keluarga, dimensi peran keluarga sangat terkait erat dengan stabilitas emosi. Peran dalam hal ini terkait erat dengan kasih sayang, saling mengahargai, memberikan sikap keteladanan dalam keluarga dan sebagainya. Dalam UU Perkawinan, kematangan emosi dapat dianalisis dari beberapa pasal yang terkait dengan hak dan kewajiban suami, isteri, dan anak.

Sedangkan permasalahan kekerasan pasangan sudah diatur dalam UU KDRT. Kekerasan pasangan tidak bisa hanya diselesaikan lewat jalur yuridis semata, namun diperlukan dengan pendekatan sosial lain, diantaranya adalah pendekatan psikologi. Adapun kontruksi hukum keluarga dengan pendekatan psikologi dalam kasus kekerasan pasangan dapat diimplementasikan dengan cara menyediakan sanksi sosial sebagai alternatif hukuman atas pelaku, menjalin kerja sama dengan lembaga psikologi agar dapat menyediakan tenaga psikolog, menyediakan pendamping hukum berprespektif perempuan yang handal, dan melakukan advokasi kebijakan yang diperlukan untuk mendukung korban KDRT dalam mencapai keadilan.[a]

\section{DAFTAR PUSTAKA}

Anissa, Nova, dan Agustin Handayani, Hubungan antara Konsep Diri dan Kematangan Emosi dengan Penyesuaian Diri Istri yang Tinggal Bersama Keluarga Suami, Jurnal Psikologi Pitutur, Vol. 1, No. 1, Juni 2012. 
Basri, Hasan, "Nutrisi Cinta: Strategi Menggapai Keluarga Sakinah", Humaira: Majalah Keluarga Sakinah, Vol. I/No. 1/Mei 2013/Rajab 1434 H.

Dariyo, Agoes, Memahami Psikologi Perceraian dalam Kehidupan Keluarga, Jurnal Psikologi, Vol. 2 No. 2 Desember 2004.

David H. Olson dan Brent C. Miller (ed), Family Studies: Review Yearbook; A General Framework for Family Impact Analysis, London/Beverly Hills/ New Delhi: Sage Publiction, 1983.

Faturochman, Revitalisasi Peran Keluarga, Buletin Psikologi, Tahun IX, No. 2, Desember 2001.

Lianawati, Ester, Tiada Keadilan Tanpa KDRT Perspektif Psikologi Feminis, Yogyakarta: Paradigma Indonesia, 2009.

Mubarok, Achmad, Psikologi Keluarga, Malang: Madani, 2016.

Nasution, Khoiruddin, Arah Pembangunan Hukum Keluarga: Pendekatan Integratif dan Interkonektif dalam Pembangunan Keluarga Sakinah, $A s$ Syir'ah: Jurnall Ilmu Syari'ah dan Hukum, Vol. 46 No. I, Januari-Juni 2012.

Peraturan Jenderal Masyarakat Islam Nomor: DJ.II/542 Tahun 2013 tentang Pedoman Penyelenggaraan Kursus Pra Nikah.

Rahmawaty, Anita, "Harmoni dalam Keluarga Perempuan Karir: Upaya Mewujudkan Kesetaraan dan Keadilan Gender dalam Keluarga”, Jurnal Palastren, Vol. 8, No. 1, Juni 2015.

Thohier, Muchson, Pembekalan Pranikah: Siapa Peduli?, dalam http://m. kompasiana.com/muchson_thohier/pembekalan-pranikah-siapapeduli_552bdbbb6ea8344f418b4569 diakses tanggal 22 Januari 2017.

Tim Pusat Bahasa, Kamus Besar Bahasa Indonesia, Jakarta: Pusat Bahasa, 2008

UU Nomor 1 Tahun 1974 tentang Perkawinan.

UU Nomor 23 Tahun 2004 tentang Penghapusan Kekerasan dalam Rumah Tangga.

William M. Pinsof, Jay L. Lebow (eds.), Family Psychology: The Art of The Science, New York: Oxford University Press, 2005.

Yusdani, Menuju Fiqh Keluarga Progresif, Cet. II, Yogyakarta: Kaukaba, 2015.

Zaharuddin, Telaah Kritis terhadap Pemikiran Psikologi Islam Muhammad Utsman Najati, Psikis: Jurnal Psikologi Islami, Vol. 1, No. 2, 2015. 
42 || Volume 27, Nomor 1, April 2017 